\author{
ACTA MYCOLOGICA \\ Vol. 44 (1): 109-123 \\ 2009
}

\title{
The development of Erysiphe alphitoides and E. hypophylla in the urban environment
}

\author{
EWA SUCHARZEWSKA \\ Department of Mycology, University of Warmia and Mazury in Olsztyn \\ Oczapowskiego 1A, PL-10-719 Olsztyn-Kortowo, ewko@uwm.edu.pl
}

Sucharzewska E.: The development of Erysiphe alphitoides and E. hypophylla in the urban environment. Acta Mycol. 44 (1): 109-123, 2009.

Differentiated responses of Erysiphe alphitoides and E. hypophylla in urban conditions are described. The influence of transport pollution on the morphology of the mycelium, chasmotecium development and individual stages of the developmental cycle is discussed.

Key words: Erysiphales, developmental cycle, transport pollution, Olsztyn

\section{INTRODUCTION}

Erysiphe alphitoides Griff et Maubl. and E. hypophylla Nevod. are common obligate parasites of the order Erysiphales. They infect representatives of the genera Quercus and Fagus as well as sporadically Aesculus and Castanea. Paeonia lutea has been identified as a new host of Erysiphe hypophylla (Takamatsu et al. 2006). The two phytopathogens are widespread in entire Europe, Asia, America, Australia and New Zealand. The occurrence of Erysiphe alphitoides has been documented in Poland since 1909, initially in the conidial stage only (Oidium quercinum Thüm). The sexual stage of E. alphitoides was first observed in France in 1911 and recorded in Poland in 1922 (Braun 1995; Sałata 1985). It has since been recorded in the teleomorphic stage as Microsphaera alphitoides very often (Adamska et al. 1999; Czerniawska 2001; Dynowska et al. 1999; Kalinowska-Kucharska, Kadłubowska 1993; Kućmierz 1967, 1971, 1973; Majewski 1970, 1971; Mułenko 1981, 1988; Mułenko, Wojdyło 2002; Ruszkiewicz-Michalska 2006; Sałata et al. 1993). Erysiphe alphitoides is a dangerous oak pathogen. It attacks trees of various age classes causing a reduction in annual growth (Minkievič et al. 1993). 
Erysiphe hypophylla was first observed in Poland in 1952 (Sałata 1985). It has been recorded sporadically in different parts of Poland (Dynowska et al. 1999; Majewski 1971; Mułenko 1988; Sałata, Majewski 1976).

In contrast to Erysiphe alphitoides, the systematic position of E. hypophylla was not clear until recently (Braun, Takamatsu 2000). The species was considered by many mycologists to be a synonym of Erysiphe alphitoides (Microsphaera alphitoides) based on biometric studies. Braun et al. (2003) finally distinguished two separate species using molecular studies: Erysiphe alphitoides and Erysiphe hypophylla.

The two fungi, mostly Erysiphe alphitoides and less frequently E. hypophylla, has been reported in studies investigating their presence in floristically or phytosociologically interesting communities and ecosystems characterised by a low level of anthropopressure. As they were often inventories or phytopathological examinations, these studies usually provided systematic and geographical analyses of species richness or an assessment of taxonomic differentiation in relation to plant associations in a given area (Adamska et al. 1999; Czerniawska 2001; Majewski 1971; Mułenko 1996, 1998; Kućmierz 1971, 1973). However, the ecology Erysiphe alphitoides and E. hypophylla and their life strategies in environments exposed to strong anthropopressure have been discussed in few studies.

The aim of this study was to analyse the occurrence of Erysiphe alphitoides and $E$. hypophylla and to examine basic life reactions of the parasites in urban conditions.

\section{MATERIAL AND METHODS}

Examinations (2000-2002) were conducted in the city of Olsztyn and its vicinity at 63 sites (17 sites with young plants and 46 sites with mature Quercus robur L. plants) situated at a range of distances from main transport routes: up to $50 \mathrm{~m}$, up to $100 \mathrm{~m}$, up to $300 \mathrm{~m}$ and $>300 \mathrm{~m}$. Distances were selected using studies by Lorenc-Plucińska and Byczyńska (1997) which show that the greatest value of exhaust gas concentration is recorded at a distance of $30-50 \mathrm{~m}$ away from the road and is at a constant level of $30 \%$. The exhaust gas level drops to $10 \%$ at $200 \mathrm{~m}$ away from transport routes. Sites located $>300 \mathrm{~m}$ were used as controls.

Material was obtained from the middle of the vegetative period when first chasmothecia began to occur on the powdery mycelium. One sample was defined as a total of 25 leaves collected randomly from each host plant.

The infection rate of host plants, mycelium development and morphology as well as chasmothecium development were examined in the macro- and microscopic analysis of the material.

1. The disease rating was calculated for each sample on a $5^{\circ}$-scale using McKinney's formula. It shows the degree of infection of host plants and is a criterion of pathogen sensitivity (Dynowska 1993, 1994) to changes in the optimum environment conditions:

$$
\mathrm{R}=\frac{\sum(\mathrm{a} \times \mathrm{b}) \times 100 \%}{\mathrm{~N} \times 4}
$$


$\mathrm{R}$ - disease coefficient in percent (index); $\Sigma$ (a x b) x 100\% - the sum of the products obtained by multiplying the number of plant organs (a) by the degree of infection (b); $\mathrm{N}$ - total number of plants (alternatively leaves, fruits) examined in the study; 4 - the highest degree of infection in a five-grade scale ( 0 - no infection; 1 - up to $10 \% ; 2-11-25 \% ; 3-26-50 \% ; 4-51-100 \%$ ).

The final value $\mathrm{R}$ used in the results analysis was calculated based on the arithmetic mean for each fungal species on a specific host plant $=$ mean degree of infection.

2. The developmental stage of the parasite was identified: asexual stage, sexual stage.

3. The number of chasmothecia, both mature and immature, per $1 \mathrm{~cm}^{2}$ of the surface of each infected leaf was established. Ten randomly collected morphologically mature chasmothecia were selected and analysed under a microscope. The following were assessed:

a) developmental degree of appendages in a three-grade scale: 0 - chasmothecia without appendages, I - chasmothecia with appendages not fully developed, II chasmothecia with fully developed appendages;

b) maturity of chasmothecia in a three-grade scale: 0 - chasmothecia without asci and spores; I - chasmothecia with asci without formed ascospores; II - chasmothecia with asci containing spores;

c) morphological variability of chasmothecia, the size and diameter of chasmothecia, appendages.

The number of chasmothecia discussed in the results was calculated based on the arithmetic mean for each fugal species.

Fungi were determined using keys by Braun (1987, 1995) and Sałata (1985). Species were identified using morphological traits of chasmothecia (size and diameter, number of appendages, appendages branching).

The nomenclature was accepted after Braun and Takamatsu (2000) and Braun et al. (2003). Host plants were determined using studies by Szafer et al. (1988) and Rutkowski (1998).

Statistical calculations were conducted using the data analysis software system STATISTICA (StatSoft, Inc.) version 6 (2003) by variance analysis. Significant differences among the means were declared at a significance level of $p=0.05$. The means were then classified in homogenous groups for selected factors using Duncan's test. Letter symbols $(\mathrm{a}, \mathrm{b}, \mathrm{c} . .$.$) were used and values to which the same letters were as-$ signed do not differ significantly at $\mathrm{p}=0.05$.

\section{RESULTS}

Erysiphe alphitoides and E. hypophylla were observed on both mature and young Quercus robur plants in all the years of the study period: at 40 sites in $2000(63 \%)$, at 47 sites in 2001 (75\%) and at 48 sites in 2002 (77\%) (Fig.1).

The analysis of the degree of infection of the host plant in relation to the distance from transport routes shows noticeable, statistically significant differences. The highest mean disease index was recorded at sites located up to $100 \mathrm{~m}$ and $50 \mathrm{~m}(52 \%$ and 

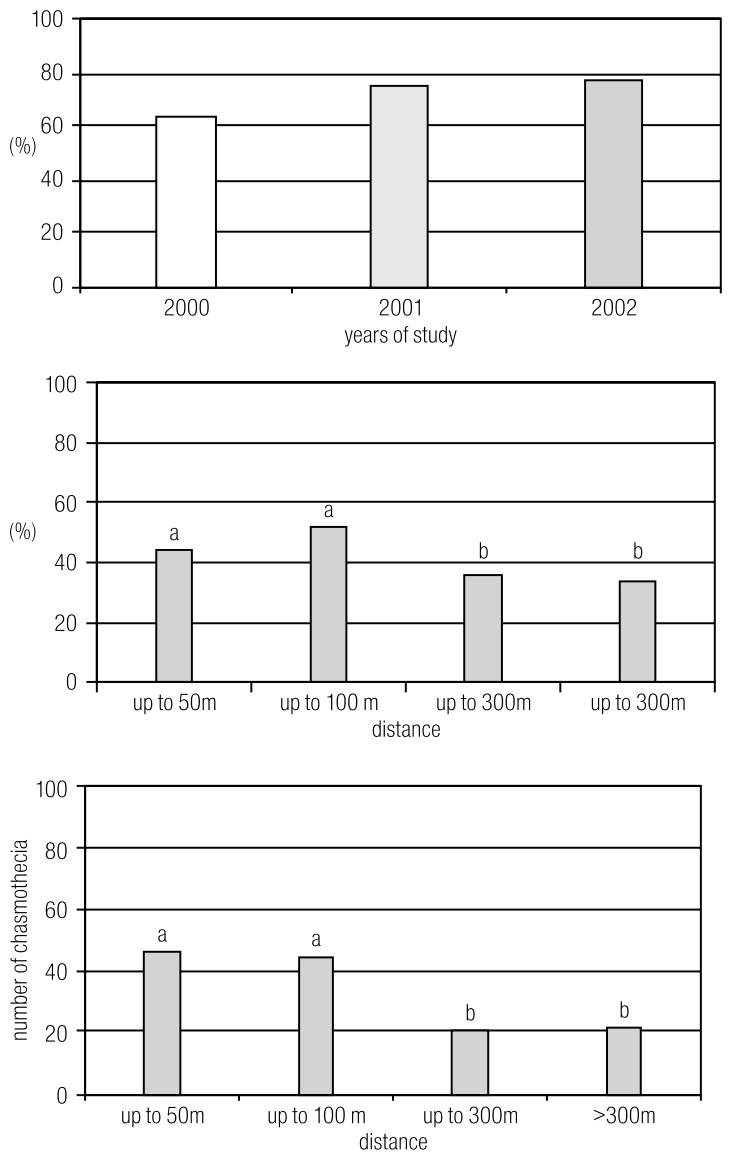

Fig. 1. Percentage participation of E. alphitoides and E. hypophylla in samples on $Q$. robur.

Fig. 2. Mean degree of infection of Q. robur by E. alphitoides and E. hypophylla in relation to the distance from transport routes in the study period (letters a and b indicate statistically significantly different values at $\mathrm{p}=0.05$ ).

Fig. 3. Mean number of E. alphitoides chasmothecia per $1 \mathrm{~cm}^{2}$ of leaf surface throughout the study period.

$44 \%$, respectively). The lowest mean infection was observed at sites located up to $300 \mathrm{~m}$ and $>300 \mathrm{~m}$, which is confirmed by the statistical analysis (Fig. 2).

The two parasites either occurred separately or co-occurred on the same plant and even on the same leaf. The upper leaf surface was usually colonised by $E$. alphitoides and the lower leaf surface by E. hypophylla. Chasmothecia of E. alphitoides were recorded beside chasmothecia of E. hypophylla on the lower leaf surface in a few cases.

A relatively high participation of the species' co-occurrence on the same leaves was recorded in each study year. Changes in the prevalence of the two fungi were also observed. E. alphitoides increased its occurrence at the distances examined in the study year by year. The highest participation of the species was recorded at sites located up to $50 \mathrm{~m}$. E. hypophylla occurred more frequently at sites located up to $300 \mathrm{~m}$ and $>300 \mathrm{~m}$ (Fig. 4 ).

Two developmental stages of E. alphitoides and E. hypophylla were observed throughout the study period: the asexual stage when conidial spores occurred and the sexual stage when chasmothecia were produced. Samples containing the perfect stage of the two fungi constituted the highest percentage regardless of the distance $(>70 \%)$. 


\begin{tabular}{|c|c|c|}
\hline E. alphitoides & E. hypophylla & E. alphitoides + E. hypophylla \\
\hline & & \\
\hline
\end{tabular}

2000
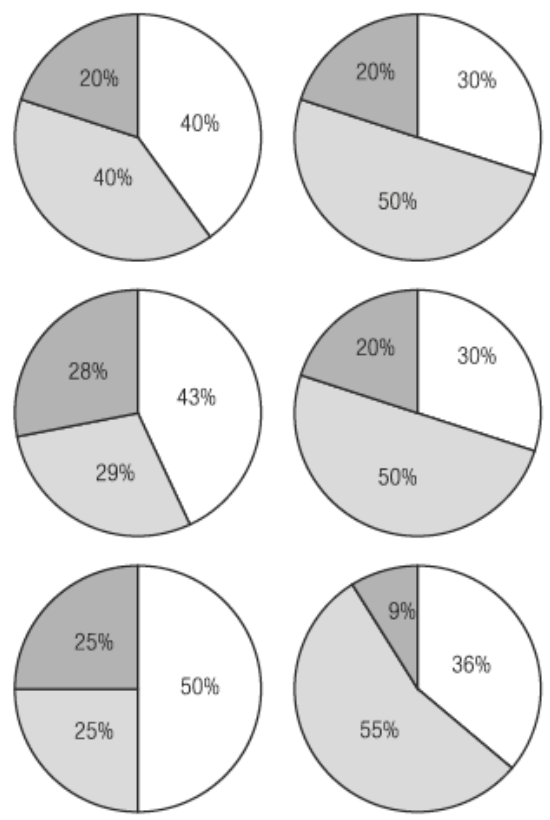
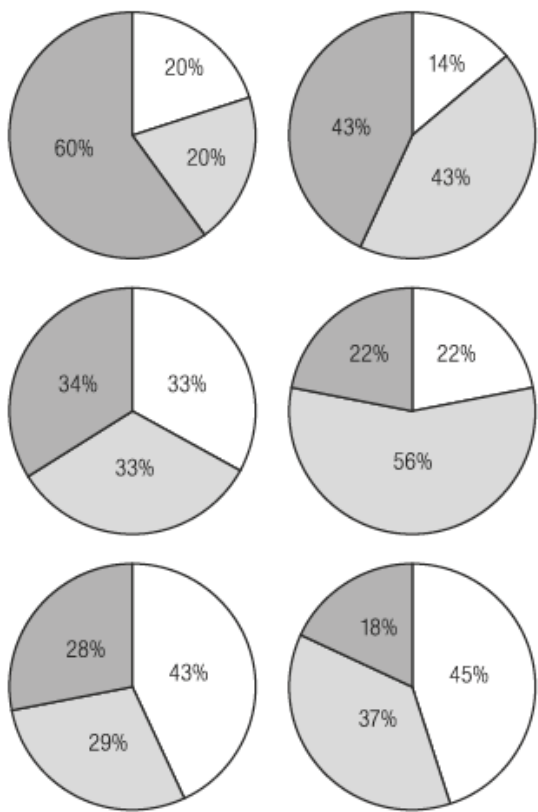

Fig. 4. Percentage participation of E. alphitoides and E. hypophylla samples at various distances throughout the study period.

The analysis of the relationship between the mean number of chasmothecia per $1 \mathrm{~cm}^{2}$ of leaf surface and the site distance shows statistically significant results only in the case of E. alphitoides. The highest means were obtained for $50 \mathrm{~m}-47 \mathrm{ch} . / \mathrm{cm}^{2}$ and the lowest means for $300 \mathrm{~m}-20 \mathrm{ch} . / \mathrm{cm}^{2}$ (Fig. 3).

Chasmothecia were always in different developmental stages, from young (white, yellow and orange) to mature (brown and dark brown), in both species in all the zones examined in the study. Significant differences in the percentage participation of young and mature chasmothecia depending on the distance were not observed either in E. alphitoides or in E. hypophylla.

Different developmental stages of appendages in morphologically mature chasmothecia (dark brown chasmothecia were defined as mature) were recorded in all the zones. In E. alphitoides, chasmothecia without appendages ( 0 stage) and appendages in the first developmental stage, not fully developed, constituted the greatest percentage (Fig. 5).

However, the greatest participation of appendages in the first (I) and second (II) developmental stages was observed in E. hypophylla. Chasmothecia without appendages constituted a very small percentage in all the zones throughout the study period (Fig. 6).

No relationship between the level of appendage development in chasmothecia and the distance from transport routes was shown statistically. The correlation analysis 


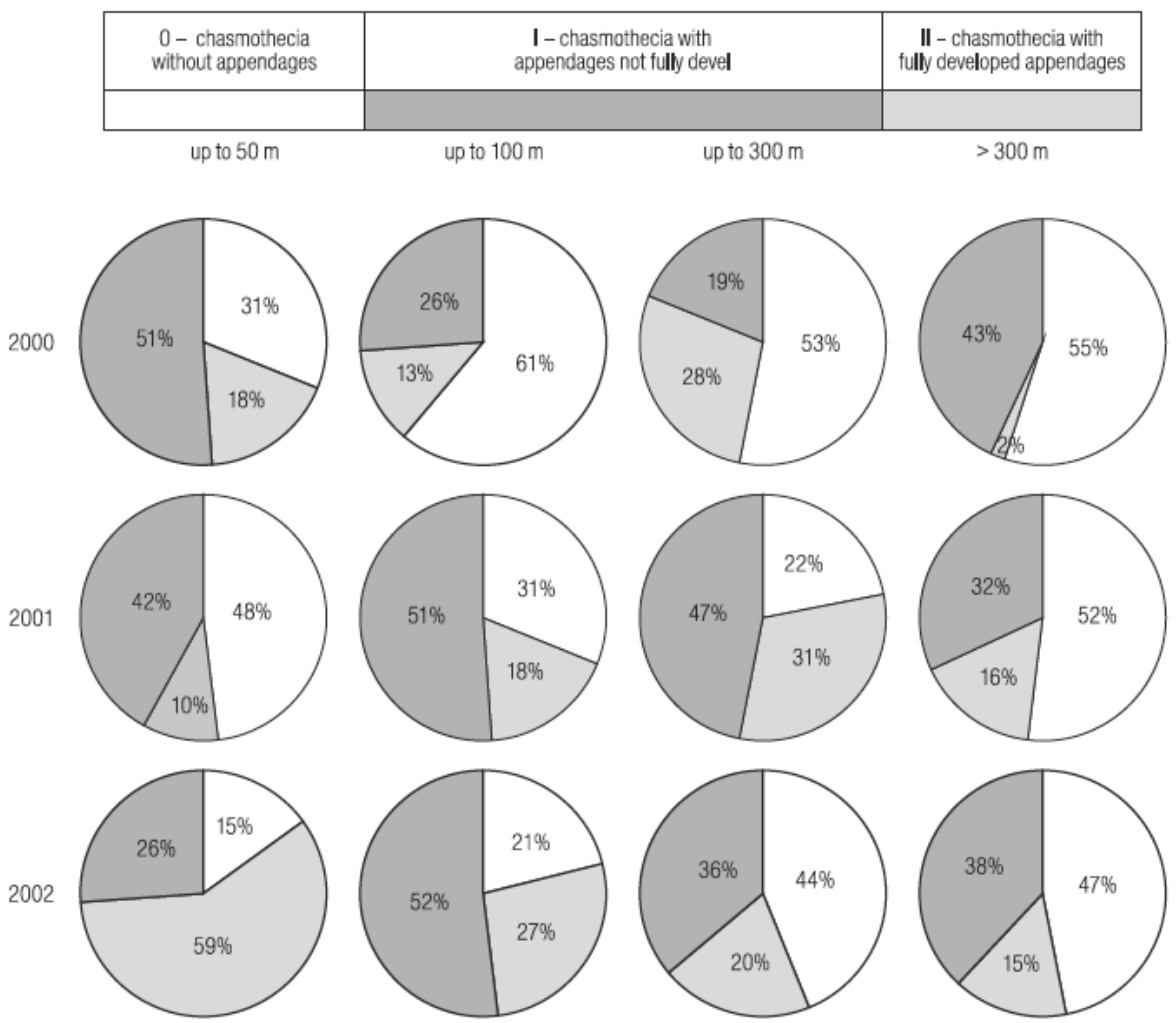

Fig. 5. Percentage participation of chasmothecia having appendages in various developmental stages in E. alphitoides.

showed that the participation of chasmothecia of E. alphitoides and E. hypophylla having developed appendages increased as the mean number of chasmothecia increased.

Chasmothecia having untypical appendages characterised by abnormal branching (branching hypha-like and branched dichotomously at half the length) were observed in a few cases in E. alphitoides at $50 \mathrm{~m}$ and $100 \mathrm{~m}$. They constituted only $1 \%$. The statistical analysis showed a relationship between the number of chasmothecia per $1 \mathrm{~cm}^{2}$ and the presence of untypical appendages. The number of chasmothecia having untypical appendages increased as the number of chasmothecia increased.

The analysis of asci and ascospores did not show statistically significant differences in relation to the distance from transport routes. However, distinct interspecific differences were observed. Chasmothecia containing asci and spores as well as chamsothecia containing asci without ascospores had the greatest participation in the majority of cases in E. alphitoides. The participation of chasmothecia without asci and spores was also high (Fig.7). Chasmothecia without asci and spores (stage 0 ) constituted a very low percentage $(<4 \%)$ in E. hypophylla (Fig. 8).

The correlation analysis showed that the participation of chasmothecia with asci containing ascospores increased together with the mean number of chasmothecia, an increase in the number of mature chasmothecia and an increase in the number of chasmothecia having appendages in stages I and II of development in E. alphitoides and E. hypophylla. 


\begin{tabular}{|c|c|c|}
\hline $\begin{array}{c}0-\text { chasmothecia } \\
\text { without appendages }\end{array}$ & $\begin{array}{c}\text { I-chasmothecia with } \\
\text { appendages not fully developed }\end{array}$ & $\begin{array}{c}\text { II - chasmothecia with } \\
\text { fully developed appendages }\end{array}$ \\
\hline & & \\
\hline
\end{tabular}

up to $50 \mathrm{~m}$

up to $100 \mathrm{~m}$

up to $300 \mathrm{~m}$

$>300 \mathrm{~m}$
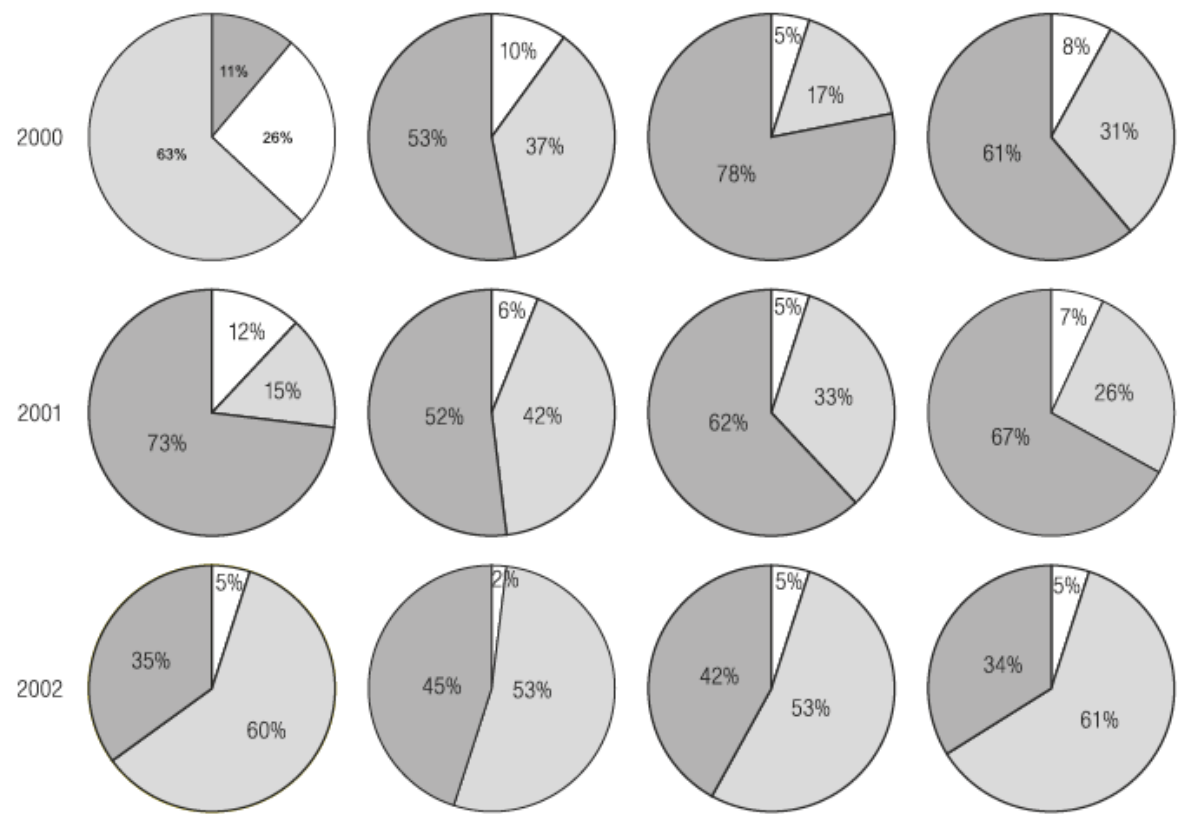

Fig. 6. Percentage participation of chasmothecia having appendages in various developmental stages in E. hypophylla.

Stages 0 and I of appendage development were always observed in chasmothecia that had not produced asci and spores in both species. However, untypical chasmothecia that had normally developed appendages in stage II and did not contain asci and spores were observed among perithecia of $E$. alphitoides at sties located at $50 \mathrm{~m}$ away from transport routes. They were considerably smaller than typical chasmothecia: their size ranged from $41 \mu \mathrm{m}$ to $64 \mu \mathrm{m}$, the number of appendages was between 3 and 12, and appendage length ranged from $92 \mu \mathrm{m}$ to $153 \mu \mathrm{m}$. The greatest mean number of chasmothecia was also recorded at these sties.

\section{DISCUSSION}

Strong disease symptoms caused by pathogenic fungi are not observed in natural communities where the biological balance is preserved (Mulenko 1998). Progressing human-induced degradation of the environment leads to an imbalance in adaptation mechanisms of all its components and, as epiphytoses show, seriously upsets the operation of biological systems. The intensification of some fungal diseases, including 


\begin{tabular}{|c|c|c|}
\hline $\begin{array}{c}0-\text { chasmothecia } \\
\text { without asci and spores }\end{array}$ & $\begin{array}{l}\text { I-chasmothecia with asci } \\
\text { without formed ascospores }\end{array}$ & $\begin{array}{c}\text { II - chasmothecia } \\
\text { with asci containing sp }\end{array}$ \\
\hline & & \\
\hline
\end{tabular}

up to $50 \mathrm{~m}$
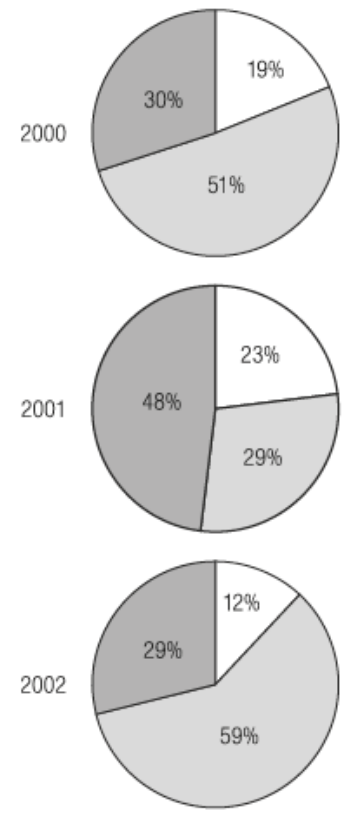
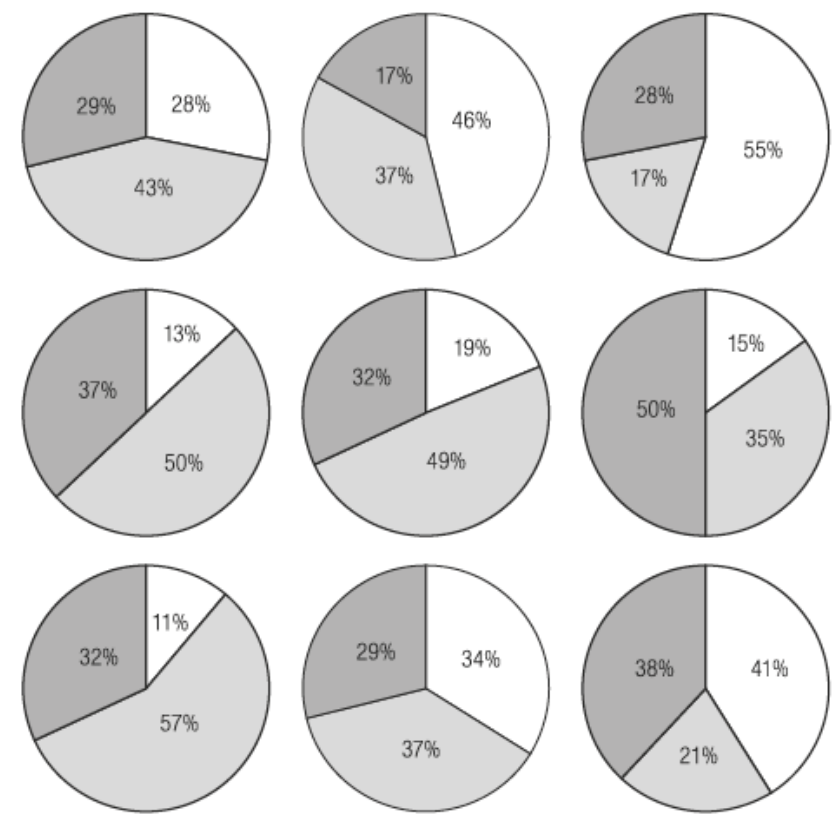

Fig. 7. Percentage participation of chasmothecia having different degrees of maturity in E. alphitoides.

those caused by powdery mildews, in environments affected by human intervention in recent years has been reported in studies by Jarvis et al. (2002) and Knops et al. (1999). Several fungal species fully realise their life functions in the environment of the city, often described as an urbicenosis (Sudnik-Wójcikowska 1998). Urbanophiles are defined Sudnik-Wójcikowska as organisms that find urban conditions favourable for development, in contrast to urbanophobes. The present study shows that Erysiphe alphitoides and E. hypophylla are urbanophiles. Both species occurred in each year of the study period and a rise in the activity of Erysiphe alphitoides was observed at the most polluted sites where the degree of infection of the host plant could reach up to $100 \%$. Present results on the occurrence of Enysiphe alphitoides on oaks do not correspond with studies by some authors who considered the species to be sensitive to various types of pollution, both transport and industrial pollution. The absence of the parasite in the vicinity of motorways was observed by Flückiger and Oertli (1978). Dynowska (1996, 1996a) recorded a considerably lower degree of infection of oaks in the vicinity of transport routes in different cities and towns in north-eastern Poland in comparison with regions outside urban areas. A low degree of $Q$. robur infection by E. alphitoides or the disappearance of the species in species polluted by the industry are reported by Benben \& Sierota (1976), Grzywacz \& Ważny (1973) and Kowalski \& Wrzalik (1996). The latter believe that pollution 


\begin{tabular}{|l|l|c|}
\hline $\begin{array}{c}0 \text { - chasmothecia } \\
\text { without asci and spores }\end{array}$ & $\begin{array}{c}\text { I-chasmothecia with asci } \\
\text { without formed ascospores }\end{array}$ & $\begin{array}{c}\text { II- chasmothecia } \\
\text { with asci containing spores }\end{array}$ \\
\hline & & \\
\hline
\end{tabular}
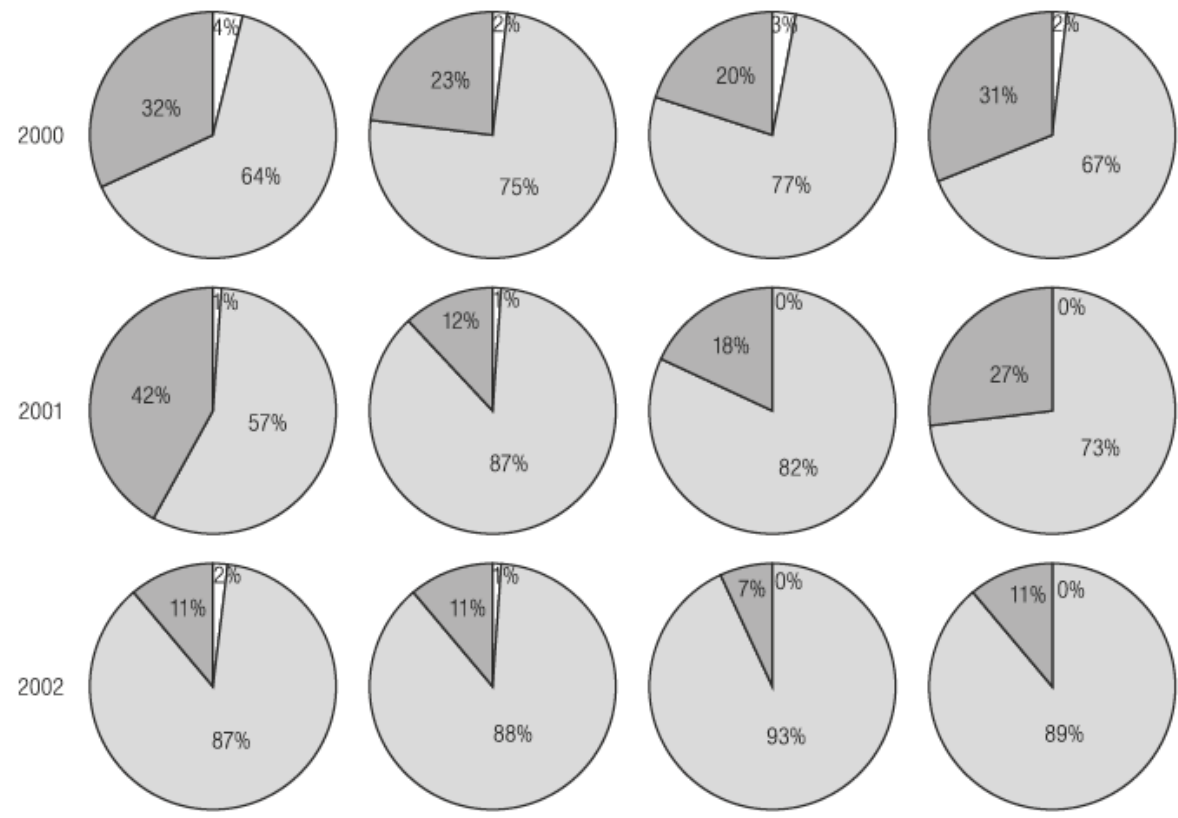

Fig. 8. Percentage participation of chasmothecia having different degrees of maturity in E. hypophylla.

indirectly influences the disappearance of the powdery mildew on oaks while it has a direct impact on the condition of the host plant. Dynowska (1996a) suggests that adaptation processes of the entire parasite-host system should be analysed. Reduced immunity of host plants cannot be excluded as the success of the initiation of the parasitic contact and the full development of the parasite depend on the host's health condition.

A high level of oak infection recorded in the present study is likely to result from the poor health condition of the plants in urban conditions. A noticeable downward trend in the level of sulphur dioxide in air has been observed in Olsztyn in the last few years. However, a steady, high level of nitrogen dioxide concentration $\left(\mathrm{NO}_{2}\right)$ which, as tests conducted by the Voivodeship Sanitary and Epidemiological Station in Olsztyn show, reaches highest values at very busy junctions and is considerably lower on the outskirts and outside the city, is alarming. Automotive exhaust gases distrub basic life processes in plants (Lorenc-Plucińska, Byczyńska 1997) while nitrogen compounds diluted in plant tissues are used by some pathogens to degrade phenols synthesised by host plants as inhibitors. This may stimulate the development of parasites (Bell, Treshow 2002). A mass occurrences of powdery mildews in Toruń has also been observed by Hołownia and Kostrzewska (1991), who believe such phenomena could be caused by air pollution. An epiphytositic occurrence of 
E. alphitoides in areas strongly influenced by pollution has also been observed by Boczoń (1998) and Domański et al. (1987). Divergent results of research into the occurrence of $E$. alphitoides is explained by Domański (1976). He attributes epiphytoses to a specific system of ecological factors that favourably influence the development as well as aggressiveness and pathogenecity of the disease agent. A set of factors co-interacting in different combinations most probably occurred in each of the above cases and may have influenced divergent study results. This was shown in a study by Grzebyta et al. (2005), who analysed the influence of high temperature and fluoride on the development of E. alphitodes on $Q$. robur: higher infection of leaves in oaks growing in an area containing fluoride than in a clean area was recorded in previous observations. This indicated a low sensitivity of the pathogen to pollution with fluoride compounds. More detailed examinations, however, showed that fluoride which acted synergistically with high temperature caused the opposite effect and led to low infection of leaves.

Erysiphe hypophylla, which mostly colonised the lower leaf surface similarly to E. alphitoides, developed in all the distance zones. Its strongest development was observed at sites up to $300 \mathrm{~m}$ and at control sites. Interestingly, the species co-occurred on the same leaves and the percentage of the occurrence of this type was high in the distance zones in the three study years. Information on the occurrence of biology of E. hypophylla is scarce in the available literature. It was recorded in the Białowieża National Park by Majewski (1971) and at a few localities in Poland by Sałata \& Majewski (1976) and Dynowska et al. (1999). The species seems to be common and the present study shows that it often occurs along with E. alphitoides. However, the presence of the latter is recorded in many Polish studies (Adamska et al. 1999; Czerniawska 2001; Kalinowska-Kucharska, Kadłubowska 1993; Mułenko, Wojdyło 2002). These studies are conducted mostly in environments similar to natural ones where the degree of anthropogenecity is low. These results, however, cannot be used to define the occurrence of E. hypophylla in urbanised and natural areas. Divergent opinions on the separate position of the two parasites and their treatment as one species, Erysiphe (Microsphaera) alphitoides, may have also contributed to this.

Weather conditions also influenced the development of the two species in the study period. Erysiphales can infect plants in a broad range of temperatures and humidity. Due to a considerable amount of water in the cell, spore germination in the majority of the representatives of the order takes places even in low relative air humidity. The highest degree of infection in all the species analysed in the study was observed in 2002 when the vegetative period was very warm and dry. July, August and September were hot while precipitation between May and September was lower than usual. Similar results were obtained by Durska (1974), who recorded an increased development of Erysiphales during a dry and hot summer.

Parasites aim to close the developmental cycle in order to produce structures having the best possible resistance genes that condition the survival of a species. Therefore, a strategy aimed at increasing and improving reproduction is a characteristic trait of parasites. Organisms whose features are better adapted to their environments achieve a greater reproduction success. The sexual process may be disturbed in unfavourable conditions, such as pollution, which may result in the absence of or a reduction in the number of ascomata or degeneration. This was observed in Lophodermium pinastrii by Grzywacz (1976) as well as by Kowalski and 
Budnik (1976). The parasite could not reach a full developmental cycle due to high concentrations of toxic compounds and altered chemism of infected needles, and did not produce ascomata.

A full developmental cycle of the two powdery mildews that ended in the production of chasmothecia, also called cleistothecia, characteristic of this fungal group, was observed in the present study. Chasmothecia in the order Erysiphales are sclerotia and their initiation occurs in unfavourable environmental conditions according to some researchers (Dynowska 1996a; Füzi 2001). Literature data show that the majority of powdery mildews enter the reproduction stage towards the end of the vegetative period, between August and November (Füzi 2001; Majewski 1971; Mmbaga 2002; Sałata 1985; Turnau, Czerwonka 1986). Present results corresponds with literature reports. Young chasmothecia in Erysiphe alphitoides and Erysiphe hypophylla were observed at most sites at the beginning of August. They began to mature in the second half of August and mature chasmothecia were recorded in mid September. Similar results were obtained by Kadłubowska, Kalinowska-Kucharska (1989) and Minkievič et al. (1993). However, the parasites did not always enter the generative stage. The fact that the Oidium form was recorded towards the end of the study periods suggests that the sexual stage is not obligatory in the species and the parasite also overwinters in the anamorphic form. Majewski (1971) also observed that not all powdery mildews enter the teleomorphic stage in his studies in the Białowieża National Park.

Statistically significant differences in the number of chasmothecia between the zone influenced by automotive exhaust gases and the control zone were observed in Erysiphe alphitoides. Parasites formed chasmothecia more numerously at a distance up to $50 \mathrm{~m}$ away from transport routes and their smallest number was recorded $>300$ $\mathrm{m}$. This may result from the differences in the degree of infection of the host plant. A similar opinion was expressed by Füzi (2001), who observed a strict correlation between the number of chasmothecia and the degree of infection: both variables were mutually dependent. Mmbaga (2002) disagrees and reports that neither the degree of infection of the host (leaves with a low infection degree often contained a high number of chasmothecia) nor the plant age influences the number of chasmothecia. Significant disturbances in chasmothecium development at sites located by main transport routes were not observed in the two powdery mildews.

It is interesting that differences in appendage development were observed between the two mildews infecting $Q$. robur. A considerably greater number of chasmothecia without appendages (0 developmental stage) and having appendages not fully developed (I developmental stage) were recorded in E. alphitoides. Chasmothecia having appendages in I and II developmental stage dominated in E. hypophylla. The lower leaf surface may have been more favourable for the development of chasmothecia. This is reflected in the maturity of asci and spores. A high participation of chasmothecia without developed asci and spores was recorded in E. alphitoides while chasmothecia with asci containing spores constituted a considerably higher percentage in E. hypophylla.

Untypical chasmothecia whose size was considerably smaller and which did not have developed asci and spores but had fully developed appendages and chasmothecia with untypical appendages were observed in Erysiphe alphitoides. These chasmothecia were recorded in the zone up to $50 \mathrm{~m}$ in 2002. Empty chasmothecia have been 
described in Epichlöe typhina in athropogenic populations of Pucciniella distans and attributed to disturbances in the genetic control of the developmental cycle of $E$. typhina caused by an environmental factor (Falińska 2002). Degenerated chasmothecia of a considerably smaller size were observed in Lophodermium pinastrii in the zone of the strongest influence of pollution by Benben, Sierota (1976) and Grzywacz (1976). Empty chasmothecia as well as untypical appendages in polluted sites recorded in the present study may indicate developmental disturbances. However, such chasmothecia constituted a very low percentage. Their occurrence may thus be caused natural disturbances resulting from the formation of a great number of chasmothecia or the influence of higher temperatures as suggested by Moore-Landecker (1992).

Ecological research into the parasites of the order Erysiphales conducted in the urban environment does not unambiguously show the influence of individual factors on the development of the fungi examined in this study. However, the two species have a broad ecological amplitude. This is connected with adaptation processes conditioned by genetic mechanisms that are activated at times of greater and more longterm amplitudes of environmental factors that are characteristic of urbinocenoses (Stearns 1992).

\section{CONCLUSION}

The absence of major disturbances in the life cycles of E. alphitoides and E. hypophylla, the occurrence of all developmental stages with the predominance of the perfect stage and a high rate of infection of the host plants in the vicinity of transport routes show a high adaptation degree of the two fungi in the environment strongly affected by anthropopressure.

\section{REFERENCES}

Adamska I., Madej T., Czerniawska B., Błaszkowski J. 1999. Parasitic and saprotrophic fungi from Słowiński National Park. Acta Mycol. 34 (1): 97-103.

Bell J.N.B., Treshow M. 2002. Zanieczyszczenie powietrza, a życie roślin. WN-T. Warszawa, 526 pp.

Benben K., Sierota Z. 1976. Grzyby pasożytnicze na aparacie asymilacyjnym drzew i krzewów wokół Zakładów Azotowych w Puławach. Sylwan 10: 21-26.

Boczoń A. 1998. Występowanie grzybów chorobotwórczych w drzewostanach Nadleśnictwa Bełchatów znajdujących się pod wpływem oddziaływania przemysłu. Sylwan.11: 109-117.

Braun U. 1987. A monograph of the Erysiphales (powdery mildews). Nova Hedwigia 89: 1-700.

Braun U. 1995. The powdery mildews (Erysiphales) of Europe. Gustav Fischer Verlag. Jena, Stuttgart. New York, 337 pp.

Braun U., Cunnington J.H., Brielmaier-Liebetanz U., Ale-Agha N., Heluta V. 2003. Miscellaneous notes on some powdery mildew fungi. Schlechtendalia 10: 91-95.

Braun U., Takamatsu S. 2000. Phylogeny of Erysiphe, Microsphaera, Uncinula (Erysipheae) and Cystotheca, Podosphaera, Sphaerotheca (Cystotheceae) inferred from rDNA ITS sequences - some taxonomic consequences. Schlechtendalia 4: 1-33.

Czerniawska B. 2001. Erysiphales of the Drawski Landscape Park (NW Poland). Acta Mycol. 36 (1): 67-80.

Domański S. 1976. Grzyby występujące w drzewostanach objętych szkodliwym oddziaływaniem emisji przemysłowych w Górnośląskim i Krakowskim Okręgu Przemysłowym. III. Grzyby zasiedlające 
nadziemne części drzew w drzewostanach nie przebudowanych w latach 1970-1975. Acta Agraria et Silvestria 16: 35-60.

Domański S., Kowalski S., Kowalski T. 1987. Emisje przemysłowe a działalność patogeniczna i zmiany biotroficzne grzybów ze szczególnym odniesieniem do GOP i KOP. II Krajowe Sympozjum „Reakcje biologiczne drzew na zanieczyszczenia przemysłowe. Kórnik: 281-288.

Durska B. 1974. Studia nad grzybami pasożytniczymi roślin występujących w litoralu zbiorników wodnych Pojezierza Mazurskiego. Acta Mycol. 10 (1): 73-141.

Dynowska M. 1993. Wrażliwość niektórych grzybów pasożytniczych na zanieczyszczenia miejskie. Mat. z Symp. „Biotyczne środowisko uprawne, a zagrożenie chorobowe roślin”. 7-9 września Olsztyn: 157-161.

Dynowska M. 1994. A comparison of urban and suburban occurence of Erysiphales with special emphasis on degree of host infection. Acta Soc. Bot. Pol. 63 (3/4): 341-344.

Dynowska M. 1996. Attempt at application of Microsphaera alphitoides Griff. et Maubl. in bioindication. Phytopathol. Polonica 11: 93-96.

Dynowska M. 1996a. Próby zastosowania Erysiphales w bioindykacji. Mat. z Symp. „Nowe kierunki w fitopatologii”. 11-13 września. Kraków: 1-4.

Dynowska M., Fiedorowicz G., Kubiak D. 1999. Contributions to the distribution of Erysiphales in Poland. Acta Mycol. 34 (1): 79-88.

Falińska K. 2002. Przewodnik do badań biologii populacji roślin. PWN. Warszawa, 587pp.

Flückiger W., Oertli J.J. 1978. Der Einfluss verkehrsbedingter Luftverunreinigungen auf den Befall der Eiche durch Microsphaera alphitoides. Phytopathologische Zeitschrift 93: 363-366.

Füzi I. 2001. Importanace of cleistothecia of grapevine powdery mildew in Hungary. Novenyvedelem 37 (5): 241-248.

Grzebyta J., Karolewski P., Żytkowiak R., Giertych M.J., Werner A., Zadworny M., Oleksyn M. 2005. Effects of elevated temperature and fluorine pollution on relations between the pedunculate oak (Quercus robur) and oak powdery mildew (Microsphaera alhitoides). Dendrobiology 53: 27-33.

Grzywacz A., Ważny J. 1973. The impact of industrial air pollutants on the occurrence of several important pathogenic fungi of forest trees in Poland. Eur. J. For Path. 3: 129-141.

Grzywacz A. 1976. Występowanie grzybów patogenicznych w drzewostanach Nadl. OLEK, będących pod wpływem przemysłowych zanieczyszczeń powietrza. Folia Forestalia Polonica. Seria A. 22: 149-163.

Hołownia I., Kostrzewska A. 1991. Obserwacje nad grzybami pasożytniczymi Torunia. Acta Universitatis Nicolai Copernici. Biologia 36 (74):155-163.

Jarvis W.R., Gubler W.D., Grove G.G. 2002. Epidemiology of powdery mildews in agricultural systems (In:) R. R. Belanger, W. R. Bushnell, A J. Dik, T. L. W. Carver (eds). The powdery mildews: a comprehensive treatise. APS, St Paul: 169-199.

Kadłubowska J. Z., Kalinowska-Kucharska E. 1989. Obserwacje cyklu rozwojowego Microsphaera alphitoides na liściach dębu szypułkowego z kilku stanowisk Polski Środkowej. Zesz. Probl. Post. Nauk Roln. 374: 173-185.

Kalinowska-Kucharska E., Kadłubowska J. Z. 1993. Grzyby rodziny Erysiphaceae Polski Centralnej. Spraw. z Czynn. i Pos. Nauk. ŁTN, Łódź. 67: 275-279.

Knops J.M.H., Tilman D., Haddad N.M., Naeem S., Mitchell C.E., Haarstad j., Ritchie M.E., Howe K.M., Reich P.B. Siemann E., Groth J. 1999. Effects of plant species richness on invasion dynamics, disease outbreaks, insect abundances and diversity. Ecology-Letters 2 (5): 286-293.

Kowalski T., Budnik M. 1976. Grzyby występujące w drzewostanach objętych szkodliwym oddziaływaniem emisji przemysłowych w Górnośląskim i Krakowskim Okręgu Przemysłowym. I. Próba oceny występowania Lophodermium pinastri (Schrad.) Chev. Na podstawie oznak etiologicznych na igłach sosnowych w ściole. Acta Mycol. 12: 131-139.

Kowalski T., Wrzalik T. 1996. Microsphaera alphitoides Griff. et Maubl. in air polluted areas I. Disease severity. Phytopathol. Pol. 12: 95-102.

Kućmierz J. 1967. Materiały do flory grzybów pasożytniczych Polski. Rocznik Nauk.-Dydakt. WSP w Krakowie 28: 93-107.

Kućmierz J. 1971. Grzyby pasożytnicze Ojcowskiego Parku Narodowego. III. Workowce (Ascomycetes), grzyby niedoskonałe (Deuteromycetes) - Parasitic fungi of the Ojców National Park. III. Ascomycetes, Deuteromycetes. Frag. Flor. et Geobot. 17 (3): 425-438.

Kućmierz J. 1973. Grzyby pasożytnicze w zbiorowiskach roślinnych Ojcowskiego Parku Narodowego. Ochrona Przyrody 38: 155-211. 
Lorenc-Plucińska G., Byczyńska A. 1997. Reakcje roślin na spaliny samochodowe. International Scientific Meeting. Ecophysiological aspects of plant responses to stress factors. 12-14 czerwca Kraków: 41-49.

Majewski T. 1970. Przyczynek do flory grzybów pasożytniczych Zachodniowego Pomorza. Acta Mycol. 6 (1): 77-94.

Majewski T. 1971. Grzyby pasożytnicze Białowieskiego Parku Narodowego na tle mikoflory Polski (Peronosporales, Erysiphales, Uredinales, Ustilaginales). Acta Mycol. 7: 299-388.

Minkievič I. I., Mirczev S.S., Mikaberidze M.S. 1993. Mučnistaja roza duba. Sankt Petersburg, 51 pp.

Mmbaga M. T. 2002. Ascocarp formation and survival and primary inoculum production in Erysiphe (sect. Microsphaera ) pulchra in dogwood powdery mildew. Ann. Appl. Biol. 141: 153-161.

Moore-Landecker E. 1992. Physiology and biochemistry of ascocarp induction and development. Mycol. Res. 96 (9): 705-716.

Mułenko W. 1981. Badania nad mikroskopijnymi grzybami pasożytniczymi rezerwatu leśno-torfowiskowego Brzeziczno. Ann. UMCS. Sec. C. 36 (7): 81-88.

Mułenko W. 1988 (1989). Mikroskopowe grzyby fitopatogeniczne Pojezierza Łęczyńsko-Włodawskiego. Acta Mycol. 24 (2): 125-171.

Mułenko W. 1996. Parasitic microfungi and their hosts collected on the study area. (In:) J. B. Faliński, W. Mułenko (eds). Cryptogamous plants in the forest communites of Białowieża National Park. Project CRYPTO 3. Phytocenosis 8 (N.S.). Archiv. Geobot. 6: 55-68.

Mułenko W. 1998. Mikroskopowe grzyby fitopatogeniczne w strukturze naturalnych zbiorowisk leśnych. Uniwersytet Marii Curie-Skłodowskiej. Lublin, 188 pp.

Mułenko W., Wojdyło B. 2002. Mikroskopijne grzyby pasożytnicze drzew i krzewów Arboretum Bolestraszyce. Arboretum Bolestraszyce 9: 5-14.

Ruszkiewicz-Michalska M. 2006. Mikroskopijne grzyby pasożytnicze w zbiorowiskach roślinnych Wyżyny Częstochowskiej. Monogr. Bot. 96:1-142.

Rutkowski L. 1998. Klucz do oznaczania roślin naczyniowych Polski Niżowej. PWN. Warszawa, 809 pp.

Sałata B. 1985. Flora Polska. Grzyby (Mycota). 15: Ascomycetes. Erysiphales. PWN. Warszawa-Kraków.

Sałata B., Majewski T. 1976. Materiały do poznania rozmieszczenia geograficznego Erysiphales. Część I. Rozmieszczenie w Polsce gatunków z rodzajów: Microsphaera Lev., Phyllactinia Lev. i Podosphaera Kunze. Ann. UMCS. Sec. C. 31 (5): 87-106.

Sałata B., Romaszewska-Sałata J., Mułenko W. 1993. Mikroskopowe grzyby fitopatogeniczne. Przyroda Kotliny Zakopiańskiej. Poznanie, przemiany, zagrożenia i ochrona 2: 183-207.

Stearns S.C. 1992.The evolution of life histories. Oxford Univ. Press., Oxford, 435 pp.

Sudnik-Wójcikowska B. 1998. Czasowe i przestrzenne aspekty procesu synantropizacji flory. Wyd. UW. Warszawa, $167 \mathrm{pp}$.

Szafer W., Kulczyński S., Pawłowski B. 1988. Rośliny polskie. PWN. Warszawa, 465 pp.

Takamatsu S., Bolay A., Limkaisang S., Komu-un S., To-Anun Ch. 2006. Identity of a powdery mildew fungus occuring on Paeonia and its relationship with Erysiphe hypophylla on oak. Mycoscience 47: 367-373.

Turnau K., Czerwonka M. 1986 (1988). Scanning ultrastructural ontogeny of cleistothecia in the powdery mildew Microsphaera alphitoides. Acta Mycol. 22 (2): 223-226.

\section{Rozwój Erysiphe alphitoides i E. hypophylla w środowisku miejskim}

\section{Streszczenie}

Celem pracy było prześledzenie poszczególnych etapów cyklu rozwojowego Erysiphe alphitoides i E. hypophylla oraz ocena występowania tego pasożyta na Quercus robur w warunkach poddanych silnej antropopresji. Obserwacje prowadzono na terenie miasta Olsztyna i okolic podczas trzech sezonów badawczych. Stanowiska w liczbie 63 zlokalizowane były wzdłuż głów- 
nych szlaków komunikacyjnych w odległościach do $50 \mathrm{~m}$, do $100 \mathrm{~m}$, do $300 \mathrm{~m}$ oraz $>300 \mathrm{~m}$ (kontrolne). Materiał badawczy stanowiły losowo zebrane liście z rośliny żywicielskiej.

We wszystkich latach badań E. alphitoides i E. hypophylla wystapiły na $Q$. robur z dużym nasileniem. Odnotowano stosunkowo wysoki udział wspólnego występowania obydwu gatunków na tych samych liściach.

Stwierdzono różnice w średnim stopniu porażenia rośliny żywicielskiej w zależności od odległości od szlaków komunikacyjnych. Wyniki te były istotne statystycznie. Nie odnotowano zakłóceń w rozwoju analizowanych pasożytów-obserwowano stadia anamorficzne i teleomorficzne niezależnie od odległości. U Erysiphe alphitoides, odnotowano istotne statystycznie różnice w liczbie chasmotecjów pomiędzy strefą znajdującą się pod wpływem spalin samochodowych a strefą kontrolną. Interesujące wydaje się zaobserwowanie różnicy w rozwoju przyczepek. U E. alphitoides odnotowano znacznie więcej chasmotecjów bez przyczepek oraz z przyczepkami nie w pełni rozwiniętymi. Natomiast u E. hypophylla dominowały owocniki z przyczepkami w pełni rozwiniętymi. Ma to odzwierciedlenie w dojrzałości worków i zarodników.

U E. alphitoides stwierdzono wysoki udział owocników bez wykształconych worków i zarodników, podczas gdy u E. hypophylla znacznie większy procent stanowiły chasmotecja z workami wypełnionymi zarodnikami.

W strefie do $50 \mathrm{~m}$ u Erysiphe alphitoides zarejestrowano owocniki nietypowe, o znacznie mniejszych wymiarach bez wykształconych worków i zarodników, ale z całkowicie wykształconymi przyczepkami a także owocniki ze zniekształconymi przyczepkami. 